\title{
PENGARUH KOMPENSASI, LINGKUNGAN KERJA, DAN BUDAYA ORGANISASI TERHADAP KOMITMEN ORGANISASIONAL KARYAWAN
}

\author{
Nadhifa Faisal ${ }^{1}$ \\ IGusti Ayu ManuatiDewi ${ }^{2}$
}

\author{
${ }^{1,2}$ Fakultas Ekonomi dan Bisnis Universitas Udayana (Unud), Bali, Indonesia \\ E-mail:nadhifadiva@yahoo.com
}

\begin{abstract}
ABSTRAK
Tujuan penelitian ini adalah untuk menganalisis pengaruh kompensasi, lingkungan kerja, dan budaya organisasi terhadap komitmen organisasional karyawan. Populasi penelitian ini adalah seluruh karyawan PT. Harum Indah Sari Tours \& Travel Denpasar yang berjumlah 171 orang. Teknik sampling yang digunakan adalah proportional incidental sampling dengan pendekatan Slovin sebagai metode penentuan sampel, sehingga sampel yang digunakan sebanyak 63 orang. Pengumpulan data dilakukan melalui wawancara dan kuesioner. Data dianalisis menggunakan teknik analisis regresi linier berganda. Hasil analisis data menunjukkan bahwa kompensasi, lingkungan keja, dan budaya organisasi berpengaruh positif terhadap komitmen organisasional karyawan. Hal ini dapat mengindikasikan bahwa semakin baik kompensasi, semakin baik lingkungan kerja, serta semakin kuat budaya organisasi maka akan semakin tinggi komitmen organisasional karyawan PT. Harum Indah Sari Tours \& Travel Denpasar.

Kata Kunci: kompensasi, lingkungan kerja, budaya organisasi, komitmen organisasional karyawan.
\end{abstract}

\begin{abstract}
The purpose of this study was to analyze the effects of compensation, work environment, and organizational culture on organizational commitment of employees. The population of this research is all employees of PT. Harum Indah Sari Tours \& Travel Denpasar, amounting to 171 people. The sampling technique used was proportional incidental sampling with Slovin approach as the method of determining the sample, so the sample used was 63 people. Data collection was done through interviews and questionnaires. Data were analyzed using multiple linear regression analysis techniques. The results of data analysis show that compensation, environmental policy, and organizational culture have a positive effect on organizational commitment of employees. It can be indicated that the better the compensation, the better the work environment and the stronger the organizational culture, the higher the organizational commitment of employees of PT. Harum Indah Sari Tours \& Travel Denpasar.

Keywords: compensation, work environment, organizational culture, organizational commitment of employees.
\end{abstract}




\section{PENDAHULUAN}

Sumber daya manusia memiliki peran yang sangat penting karena merupakan penggerak utama dalam pengelolaan seluruh sumber daya yang dimiliki perusahaan guna mencapai tujuan yang telah ditetapkan. Untuk mencapai visi, misi, serta tujuan organisasi diperlukan sumber daya manusia yang profesional dan memiliki dedikasi tinggi untuk dapat memberikan kontribusi maksimal bagi organisasi. Salah satu upaya yang dapat dilakukan oleh perusahaan untuk mempertahankan sumber daya manusianya ialah dengan cara melakukan pengelolaan sumber daya yang baik sehingga komitmen organisasional karyawan akan meningkat dan karyawan dapat mewujudkan visi dan misi yang menjadi tujuan perusahaanYaseen(2013).

PT. Harum Indah Sari Tours \& Travel Denpasar merupakan anak perusahaan dari Highest International Standard (HIS) Co.Ltd Jepang yang beroperasi dalam bidang pariwisata khususnya tour and travel. Perusahaan ini telah membuka banyak cabang di Indonesia dan salah satunya berlokasi di Denpasar yang sekaligus merupakan induk perusahaanuntuk seluruh anak perusahaan di Indonesia. Banyaknya perusahaan yang mulai beroperasi dalam bidang yang sama membuat jumlah pesaing semakin banyak. Keunggulan bersaing dapat tercapai jika perusahaan memiliki sumber daya manusia yang berkualitas, kompeten dan memiliki komitmen organisasional yang tinggi. Menurut Nawab \& Komal (2011), komitmen organisasional didefinisikan sebagai afiliasi dan keterlibatan karyawan dalam perusahaan yang secara umum terdiri dari tiga dimensi yaitu komitmen bersinambung, afektif, dan normatif. 
Sistem pemberian kompensasi pada organisasi digunakan untuk berbagai macam alasan, salah satunya digunakan untuk menjamin komitmen organisasional karyawan. Pernyataan tersebut didukung oleh Michael \&Harold (1993) yang mengatakan bahwabentuk-bentuk kompensasi akan dapatmemotivasi karyawan baik dalampengawasan, prestasi kerja, maupun komitmen terhadap perusahaan. Menurut Martoyo dalam Wukir (2013:84), kompensasi adalah pengaturan keseluruhan pemberian balas jasa yang diberikan organisasi (perusahaan/employers) kepada karyawan (employees) baik yang langsung berupa uang (financial) maupun bukan dalam bentuk uang (non financial).

Kompensasi harus memiliki dasar yang kuat, benar dan adil. Apabila kompensasi dirasakan tidak adil, maka akan menimbulkan rasa kecewa karyawan, sehingga karyawan yang baik akan meninggalkan perusahaan. Oleh karena itu, agar dapat mempertahankan karyawan yang baik, maka program kompensasi dibuat sedemikian rupa, sehingga karyawan yang berpotensi akan merasa dihargai dan bersedia untuk bertahan di perusahaan (Muljani, 2002). Penelitian yang dilakukan oleh Anvari et al. (2011) dan Yamali (2018) menunjukkan hubungan yang positif dan signifikan antara kompensasi dan komitmen organisasional karyawan.

Komitmen juga dapat dipengaruhi oleh lingkungan tempat karyawan bekerja. Jika lingkungan kerja dalam perusahaan kurang menunjang, misalnya fasilitas teknologi dan kenyamanan yang kurang, hubungan kerja kurang harmonis, jaminan sosial dan keamanan kurang, maka terdapat kecenderungan komitmen karyawan terhadap organisasi menjadi makin luntur (Kuntjoro, 2002). 
Lingkungan kerja yang terdiri atas lingkungan fisik dan non fisik juga merupakan bagian yang tidak kalah penting bagi kelangsungan kerja karyawan dalam menjalankan pekerjaan yang kemudian akan memunculkan interaksi antara individu dengan lingkungan kerja. Penelitian yang dilakukan oleh Ushie et al. (2015) dan Abidin (2016) mendapatkan hasil bahwa lingkungan kerja berpengaruh positif terhadap komitmen karyawan.

Perusahaan yang memiliki budaya organisasi yang kuat dapat mempunyai pengaruh yang bermakna bagi sikap dan perilaku anggotanya. Suatu organisasi untuk mencapai keberhasilan perlumembentuk dan mengembangkan suatu budaya organisasi yang mendukung terciptanya komitmen karyawan. Menurut Susanto \& Prama (2006: 120) budaya oganisasi adalah suatu sistem nilai, kepercayaan, dan kebiasaan dalam suatu organisasi yang saling berinteraksi dengan struktur sistem formalnya untuk menghasilkan norma-norma perilaku organisasi. Pemahaman budaya organisasi terhadap karyawan akan membina kohesifitas, kesetiaan, dan komitmen organisasional. Hasil penelitian yang dilakukan oleh Habib et al. (2014) dan Inanlou (2017) menujukkan bahwa budaya organisasi mempengaruhi komitmen karyawan.

Berdasarkan hasil wawancara dengan lima belas orang karyawan pada PT. Harum Indah Sari Tours \& Travel Denpasar, terdapatindikasi rendahnya komitmen organisasional karyawan. Hal tersebut terlihat dari lebih banyaknya karyawan yang menjawab tidak setuju pada butir-butir pernyataanterkait komitmen organisasional. Berdasarkan hasil wawancara dapat diduga bahwa karyawan mempunyai rasa memiliki dan kesetiaan yang rendah terhadap 
perusahaan sehingga tidak ingin menghabiskan sisa karir dan tidak akan sulit maupun merasa rugi jika meninggalkan perusahaan. Kondisi ini mengakibatkan berpindah dari satu perusahan ke perusaahaan lain dianggap etis oleh karyawan. Selain berdasarkan hasil wawancara, terdapat permasalahan yang berindikasi menimbulkan rendahnya komitmen karyawan dalam berorganisasi yang dapat diketahui melalui adanya keluhan karyawan. Hal tersebut terlihat dari adanya masalah keterlambatan pemberian gaji oleh perusahaan kepada karyawan dan gaji yang tidak sesuai dengan pekerjaan yang telah dilakukan, sehingga karyawan memilih untuk mencari pekerjaan di perusahaan lain. Selain itu, lingkungan kerja yang kurang kondusifmenyebabkan rendahnya komitmen karyawan pada perusahaan.Hal ini dapat dilihat dari kurang harmonisnya hubungan antara karyawan dan pimpinan. Permasalahan lainnya yang berkaitan dengan komitmen organisasional adalah mengenai rendahnya kontribusi karyawan dalam bekerja yang disebabkan oleh ketidaksesuaian pekerjaan yang diberikan kepada karyawan, sehingga menyebabkan para karyawan tidak sanggup menyelesaikanbeban kerja yang menjadi tanggung jawabnya.

Berdasarkan teori pertukaran sosial (social exchange theory) yang dikembangkan oleh Thibaut dan Kelley pada tahun 1959, karyawan akan menukar usaha mereka dengan perjanjian penghargaan di masa depan (Blau, 1964 dalam Korir, 2016). Meurut teori ini, karyawan yang menghargai imbalan yang diterima dari organisasinya, seperti gaji, tunjangan atau kondisi kerja, akan menunjukkan sikap kerja yang positif. Teori tersebut mengemukakan bahwa individu membentuk hubungan pertukaran sosial sejauh mereka memperoleh imbalan yang 
bermanfaat dan bahwa manfaat ini diberikan secara adil (Haar, 2006). Oleh karena itu, teori ini mengemukakan bahwa karyawan yang puas terhadap penghargaan dan tawaran yang diberikan perusahaan cenderung memiliki kinerja yang lebih tinggi, komitmen organisasional yang tinggi dan niat keluar dari perusahaan yang rendah.

Menurut Greenberg \& Baron (2003:160) komitmen organisasional ialah tingkat dimana karyawan terlibat dan berkinginan untuk tetap menjadi anggota perusahaan tempatnya bekerja.Sementara Ivancevich et al. (2007:234)mengemukakan bahwa komitmen organisasional adalah perasaan idenifikasi,keterlibatan, dan kesetiaan yang diekspresikan oleh karyawan terhadap organisasi.Berdasarkan pengertian tersebut dapat dinyatakan bahwa komitmen organisasional melibatkan tiga sikap yaitu, rasa identifikasi dengan tujuan organisasi, perasaan terlibat dalam tugas-tugas organisasi, dan perasaan setia terhadap organisasi. Karyawan-karyawan yang merasa lebih berkomitmen pada organisasi memiliki kebiasaan-kebiasaan yang bisa diandalkan, berencana untuk tinggal lebih lama dalam organisasi, dan mencurahkan lebih banyak upaya dalam bekerja. Menurut Kuntjoro (2002), komitmen organisasional merupakan rasa kepercayaan terhadap nilai-nilai organisasi, keterlibatan dan kesediaan untuk berusaha sebaik mungkin demi kepentingan organisasi, dan keinginan untuk tetap menjadi anggota organisasi. Berdasarkan pengertian tersebut, dapat dinyatakan bahwa komitmen organisasional karyawan merupakan suatu keadaan dimana karyawan sepaham dengan tujuan organisasi, memiliki perasaan yang kuat untuk 
menjadi bagian dari organisasi serta keinginan untuk melakukan yang terbaik bagi organisasi.

Menurut Puspitawati (2014), ada tiga faktor yang mempengaruhi komitmen organisasional karyawan, yaitu pertama, faktor personal yang terdiri darikepuasan kerja, kontrak psikologis, faktor pilihan pekerjaan, dan karakteristik personal. Keseluruhan faktor ini akan membentuk komitmen awal dalam berorganisasi. Kedua, faktor organisasi yang meliputi pengalaman kerja awal, cakupan pekerjaan, dan pengawasan. Keseluruhan faktor ini akan membentuk atau memunculkan tanggung jawab. Ketiga, faktor non organisasi merupakan faktor yang tidak berasal dari dalam organisasi, misalnya ada tidaknya alternatif pekerjaan lain di luar perusahaan. Stum (dalam Sopiah, 2008:164) mengemukakan ada 5 faktor yang berpengaruh terhadap komitmen organisasional, yaitu budaya keterbukaan, kepuasan kerja, kesempatan personal untuk berkembang, arah organisasi, dan penghargaan kerja yang sesuai dengan kebutuhan.

Kompensasi adalah semua pendapatan yangditerima karyawan yang berbentuk uang secara langsung atau tidak langsung yang merupakan bentuk biaya yang harus dikeluarkan perusahaan dengan harapan memperoleh imbalan berupa prestasi kerja dari karyawan (Hasibuan, 2012:117). Kompensasi merupakan salah satu faktor yang meningkatkan keinginan karyawan untuk berkomitmen terhadap organisasi. Kompensasi tidak berfungsi sebagai balas jasa semata, namun lebih dari itu, kompensasi dapat meningkatkan keinginan karyawan agar tetap berada dalam organisasi dan dapat diajak bersama-sama bertanggung jawab terhadap jalannya organisasi. Di samping itu, kompensasi 
yang adil akan menumbuhkan rasa memiliki terhadap organisasi, yang akhirnya berdampak pada tingginya komitmen karyawan pada organisasinya (Sudarwanti, 2007). Dari definisi tersebut dapat dinyatakan bahwa kompensasi merupakan balas jasa yang diberikan oleh perusahaan atas hasil kerja karyawan.

Kompensasiakan dapat meningkatkan komitmen karyawan, sehingga sangat penting bagi perusahaan untuk melakukan pengaturan kompensasi secara benar dan adil. Indikator yang digunakan untuk mengukur kompensasi menurut Simamora (2014:442) adalah 1) gaji dan upah, yaitu hak yang diterima oleh karyawan karena kontribusinya terhadap perusahaan, 2) bonus, yaitu tambahan kompensasi diluar gaji dan upah yang diberikan oleh perusahaan, 3) tunjangan, yaitu kompensasi tambahan yang diberikan berdasarkan kebijakan perusahaan terhadap semua karyawan dalam usaha untuk meningkatkan kesejahteraan mereka.

Lingkungan kerja merupakan salah satu faktor yang mempengaruhi komitmen, yang bentuknya dapat berupa lingkungan fisik seperti tempat dan sarana produksi, serta lingkungan non fisik atau psikologisseperti hubungan sosial antar personil dalam perusahaan. Basuki \& Susilowati (2005) mengemukakan bahwa lingkungan kerja adalah sesuatu yang berada dilingkungan kantor atau instansi yang dapat mempengaruhi baik secara langsung maupun tidak langsung seseorang maupun sekelompok karyawan didalam melakukan aktivitasnya.Moekijat (2003:136) mengemukakan bahwa lingkungan kerja dapat menciptakan hubungan kerja yang mengikat antara orang-orang yang ada dalam perusahaaan. Meskipun karyawan diberikan rangsangan yang layak, semangat 
kerja bisa menjadi rendah apabila lingkungan kerjanya diabaikan. Oleh karena itu,harus diupayakan agar lingkungan kerja baik dan kondusif,sehingga karyawan merasa betah diruangan kerjanya, dan bersemangat dalam melaksanakan kegiatan atau tugasnya. Dari pengertian di atas dapat dinyatakan bahwa lingkungan kerja adalah tempat, kondisi, dan keadaan sekeliling di mana karyawan melakukan pekerjan sehari-hari.

Beberapa indikator yang dapat digunakan untuk mengukur lingkungan kerja menurut Sedarmayanti (2009:146) yaitu penerangan, pencahayaan yang tidak optimal akan menghambat penyelesaian pekerjaan, menyebabkan kesalahan kerja yang pada akhirnya berdampak negatif pada efisiensi.Suhu udara, temperatur udara atau suhu udara yang terlalu panas bagi karyawan akan dapat menjadi penyebab menurunnya kinerja karyawan. Fasilitas kerja, tidak lengkapnya fasilitas yang dimiliki perusahaan akan mengakibatkan terhambatnya kelancaran kerja.Keamanan, dengan terjaminnya keamanan di perusahaan maka karyawan akan merasa tenang dan nyaman dalam bekerja.Hubungan antar karyawan, hubungan yang baik atau harmonis dengan sesama karyawan setingkat, bawahan maupun atasan yang dapat memberikan perasaaan nyaman bagi karyawan dalam perusahaan.

Budaya organisasi adalah nilai-nilai yang dianggap penting dan diyakini kebenarannya oleh setiap anggota sebagai landasan dalam menjalankan aktifitas dalam perusahaan. Budaya organisasi terbentuk dari pemikiran yang diciptakan oleh pendiri organisasi dan kemudian dikembangkan sesuai dengan kebutuhan organisasi untuk dijadikan dasar dalam bersikap dan bertindak bagi seluruh 
karyawan. Menurut Robbins (2008), budaya organisasi dimaknai sebagai filosofi dasar yang memberikan arahan bagi kebijakan organisasi dalam pengelolaan karyawan dan pelanggan. Lebih lanjut dijelaskan bahwa budaya organisasi merupakan sebuah sistem makna bersama yang dibentuk oleh para anggotanya yang sekaligus menjadi pembeda dari organisasi lain. Sistem pemaknaan bersama merupakan sekumpulan karakter inti dari nilai-nilai organisasi yang dijunjung tinggi oleh organisasi.

Menurut Mariam (2009) budaya organisasi adalah pola dasar yang diterima oleh organisasi untuk bertindak dan memecahkan masalah, membentuk karyawan yang mampu beradaptasi dengan lingkungan dan mempersatukan para karyawan di dalam organisasi. Untuk itu, budaya organisasi perlu disosialisasikan atau ditanamkan kepada para karyawan, sebagai suatu cara yang benar dalam mengkajidan menyelesaikan masalah yang dihadapi. Kreitner dan Kinicki (2005:72) membagi empat fungsi budaya organisasi, yaitu memberikan identitas organisasi kepada karyawannya, mempermudah komitmen kolektif, meningkatkan stabilitas sistem sosial, serta membentuk perilaku karyawan dengan berperan sebagai mekanisme kontrol. Dari definisi tersebut budaya organisasi dapat dinyatakan sebagai nilai-nilai dasar yang dibentuk berdasarkan pemikirian pendiri organisasi yang diyakini oleh seluruh anggota sebagai dasar untuk beraktivitas pada perusahaan.

Menurut Schein (dalam Smirnova dkk., 2017) terdapat empat dimensi yang mempengaruhi budaya organisasi, yaitusupportiveness adalah dukungandukungan dan pelatihan yang diberikan perusahaan kepada karyawannya, 
atmosphere adalah keadaan yang ada di dalam perusahaan yang membuat para karyawan merasa betah dan semangat dalam bekerja, connectedness adalah keterkaitan karyawan terhadap perusahaan yang saling membutuhkan satu sama lain, serta formalization adalah kejelasan standar atau kebijakan yang diterapkan perusahaan, sehingga mampu dijalankan oleh karyawan.

Penelitian yang dilakukan oleh Rustini (2015) mengenai pengaruh kompensasi dan lingkungan kerja pada komitmen organisasional dan implikasinya pada kinerja karyawan menunjukkan hasil bahwa terdapat pengaruh positif kompensasi terhadap komitmen organisasional. Buraidah (2013) melakukan penelitian yang mengenai pengaruh kompensasi dan motivasi kerja terhadap komitmen organisasional menghasilkan bahwa komitmen organisasional dipengaruhi oleh kompensasi. Alamelu etal. (2015) mendapatkan hasil dalam penelitiannya bahwa kompensasi mempunyai pengaruh yang positif dan signifikan terhadap komitmen organisasional. Kee et al. (2016) pada hasil penelitiannya menunjukkan adanya hubungan yang signifikan antara hubungan kompensasi dengan komitmen. Hal ini berarti komitmen organisasional akan meningkat jika karyawan merasa puas akan kompensasi yang diberikan perusahaan. Maka, semakin baik kompensasi yang diberikan kepada karyawan, maka semakin tinggi pula komitmen organisasional karyawan terhadap perusahaan.

$\mathrm{H}_{1}$ : Kompensasi berpengaruh positif terhadap komitmen organisasional karyawan. 
Penelitian yang dilakukan oleh Shalahuddin (2013)mengenai pengaruh kepemimpinan dan lingkungan kerja terhadap komitmen organisasional dan kinerja memberikan hasil bahwa lingkungan kerja berpengaruh positif signifikan terhadap komitmen organisasional. Saputra (2017) melakukan penelitian yang mengenai pengaruh lingkungan kerja terhadap komitmen organisasional melalui kepuasan kerja karyawan memberikan hasil bahwa lingkungan kerja berpengaruh positif signifikan terhadap komitmen organisasional. Dalam penelitian yang dilakukan oleh Hanaysha (2016) mengenai pengaruh keterlibatan karyawan, lingkungan kerja, dan pembelajaran organisasi terhadap komitmen organisasional mendapatkan hasil bahwa lingkungan kerja berpengaruh positif dan signifikan terhadap komitmen organisasional. Penelitian yang dilakukan oleh Okeoghene (2016) mendapatkan hasil lingkungan kerja berpengaruh positif signifikan terhadap komitmen organisasional. Lingkungan kerja merupakan faktor penting dalam meningkatkan komitmen organisasional. Maka semakin baik lingkungan kerja semakin tinggi pula komitmen organisasional karyawan terhadap perusahaan $\mathrm{H}_{2}$ : Lingkungan kerja berpengaruh positif terhadap komitmen organisasional karyawan.

Penelitian yang dilakukan oleh Fauzi dkk. (2016) menunjukkan hasil bahwa budaya organisasi mempunyai pengaruh positif dan signifikan terhadap komitmen organisasional. Latib dkk. (2016) melakukan penelitian yang mengenai pengaruh budaya organisasi, komitmen organisasional mendapatkan hasil bahwa ada pengaruh positif dan signifikan budaya organisasi terhadap komitmen organisasional. Sinha etal.(2017) dalam penelitiannya mengenai pengaruh budaya organisasi terhadap komitmen organisasional karyawan mendapatkan hasil bahwa 
budaya organisasi memiliki pengaruh yang positif signifikan terhadap komitmen organisasional. Penelitian yang dilakukan oleh Hamidi et al. (2017) mendapatkan hasil bahwa budaya organisasi berpegaruh signifikan terhadap komitmen karyawan.Perusahaan dengan budaya organisasi yang kuat akan menghasilkan karyawan dengan komitmen yang tinggi terhadap perusahaan. Maka, semakin kuat budaya organisasional semakin tinggi pula komitmen organisasional karyawan terhadap perusahaan.

$\mathrm{H}_{3}$ : Budaya organisasi berpengaruh positif terhadap komitmen organisasional karyawan.

\section{METODE PENELITIAN}

Desain penelitian yang digunakan pada penelitian ini digolongkan pada penelitian asosiatif kausalitas karena bertujuan untuk menganalisis pengaruh dari beberapa variabel bebas terhadap satu variabel terikat. Metode ini digunakan untuk mengetahui pengaruh antara variabel kompensasi $\left(\mathrm{X}_{1}\right)$, lingkungan kerja $\left(\mathrm{X}_{2}\right)$, dan budaya organisasi $\left(\mathrm{X}_{3}\right)$ sebagai variabel bebas serta variabel komitmen organisasional karyawan (Y) sebagai variabel terikat.

Lokasi penelitian ini adalah PT. Harum Indah Sari Tours \& Travel Denpasar yang berlokasi di Jl. By Pass Ngurah Rai No.732, Pedungan, Denpasar Selatan, Kota Denpasar, Bali. Perusahaan ini dipilih sebagai lokasi penelitian karena terdapat indikasi adanya masalah yang menyangkut komitmen organisasional pada karyawannya.

Populasi dalam penelitian ini adalah seluruh karyawan yang bekerja pada PT. Harum Indah Sari Tours \& Travel Denpasar yang berjumlah 171 orang.Teknik sampel yang digunakan dalam penelitian ini adalah 
proportionalincidental sampling, sedangkan metode penentuan sampel yang digunakan dalam penelitian ini mengacu pada pendekatan slovin (Sugiyono, 2013 : 78) dengan rumus sebagai berikut:

$$
n=\frac{\mathrm{N}}{N \cdot a^{2}+1}
$$

Dimana :

$n=$ Jumlah sampel

$\mathrm{N}=$ Jumlah populasi

$\mathrm{d}=$ Persentase kelonggaran kesalahan pengambilan sampel yang masih dapat ditolerir, dalam penelitian ini digunakan persentase kesalahan $10 \%$.

Menurut rumus tersebut, besarnya sampel yang digunakan dalam penelitian ini adalah sebagai berikut:

$$
n=\frac{\mathrm{N}}{N \cdot d^{2}+1}=\frac{171}{\left(171 \cdot 0,1^{2}\right)+1}=\frac{171}{2,71}=63,09=63
$$

Tabel 1.

Data Jumlah Populasi dan Sampel

PT. Harum Indah Sari Tours \& Travel Denpasar

\begin{tabular}{llcc}
\hline No & Department/Bagian & Populasi(orang) & Sampel (orang) \\
\hline 1. & Marketing & 18 & 7 \\
2. & Human Resources \& General Affair & 9 & 3 \\
3. & Information \& Technology(IT) & 3 & 1 \\
4. & Security & 11 & 4 \\
5. & Driver & 5 & 2 \\
6. & Cleaning Service & 2 & 1 \\
7. & Accounting & 19 & 7 \\
8. & Hoterip & 11 & 4 \\
9. & Skyhub & 25 & 9 \\
10. & Reservation & 32 & 12 \\
11. & Guest Relation Officer & 36 & 13 \\
& Total & 171 & 63 \\
\hline
\end{tabular}

Sumber: Data diolah, 2018

Alat analisis yang digunakan untuk menjawab tujuan penelitian ini adalah regresi linear berganda yang merupakan suatu prosedur statistik dalam menganalisis pengaruh variabel bebas $\left(\mathrm{X}_{1}, \mathrm{X}_{2}, \mathrm{X}_{3}\right)$ terhadap variabel terikat $(\mathrm{Y})$ dengan persamaan sebagai berikut(Suyana, 2016:93): 


$$
Y=u+\beta_{1} X_{1}+\beta_{2} X_{2}+\beta_{3} X_{3}+\mu
$$

Keterangan :

$$
\begin{aligned}
& \mathrm{Y}=\text { Komitmen organisasional karyawan } \\
& \mathrm{X}_{1}=\text { Kompensasi } \\
& \mathrm{X}_{2}=\text { Lingkungan kerja } \\
& \mathrm{X}_{3}=\text { Budaya organisasi } \\
& \alpha=\text { Konstanta } \\
& \beta_{1-} \beta_{3}=\text { Koefisien regresi dari } \mathrm{X}_{1}-\mathrm{X}_{3}
\end{aligned}
$$

\section{HASIL PENELITIAN DAN PEMBAHASAN}

Adapun interpretasi data karakteristik responden pada perusahaan, yaitu karyawan yang berjenis kelamin laki-laki hampir sama dengan perempuan yang bekerja di PT. Harum Indah Sari Tours \& Travel Denpasar dengan presentase 51 persen. Tingkat usia dominan pekerja di perusahaan adalah dari usia 21-30 tahun, karena usia tersebut adalah usia yang tergolong produktif, kreatif, dan pekerja keras, sehingga dapat berkontribusi lebih baik untuk perusahaan. Tingkat pendidikan karyawan S1 lebih banyak dibandingkan karyawan yang memiliki tingkat pendidikan Diploma maupun Strata, karena pekerjaan yang terdapat di perusahaan lebih banyak membutuhkan keahlian, pengetahuan, pemahaman serta skill disetiap bidangnya. Masa kerja karyawan di PT. Harum Indah Sari Tours \& Travel Denpasarberkisar dari 1-25 tahun, dimana masa kerja karyawan yang paling banyak adalah masa kerja 1-5 tahun yang berjumlah 48 orang. Masa kerja pendek ini disebabkan karena perusahaan melakukan perekrutan karyawan baru untuk memenuhi jabatan yang kosong.

Analisis regresi linier berganda bertujuan untuk mengetahui pengaruh suatu variabel terikat dengan satu atau lebih variabel bebas. Adapun hasil analisis 
regresi dengan program Statitical Package For Social Science (SPSS)dapat dilihat pada Tabel 2.

Tabel 2.

Rangkuman Hasil Analisis Regresi Linier Berganda

\begin{tabular}{|c|c|c|c|c|c|}
\hline \multirow[t]{2}{*}{ Variabel } & \multicolumn{2}{|c|}{$\begin{array}{l}\text { Unstandardized } \\
\text { Coefficiemts }\end{array}$} & \multirow{2}{*}{$\begin{array}{c}\text { Standardized } \\
\text { Coefficients } \\
\text { Beta }\end{array}$} & \multirow[t]{2}{*}{$\mathbf{t}$} & \multirow[t]{2}{*}{ Sig. uji } \\
\hline & B & Std. error & & & \\
\hline (constant) & $-5,352$ & 2,819 & & $-1,899$ & 0,062 \\
\hline Kompensasi & 0,935 & 0,289 & 0,295 & 3,241 & 0,002 \\
\hline Lingkungan kerja & 0,538 & 0,189 & 0,304 & 2,847 & 0,006 \\
\hline Budaya organisasi & 0,327 & 0,087 & 0,376 & 3,743 & 0,000 \\
\hline Dependent variable & \multirow{2}{*}{\multicolumn{3}{|c|}{0,740 : Komitmen Organisasional Karyawan }} & & \\
\hline Adjusted R Square: & & & & & \\
\hline F Statistik & $: 59$ & & & & \\
\hline Sig F & & & & & \\
\hline $\mathrm{R}^{2}$ & 0 & & & & \\
\hline
\end{tabular}

Sumber:Data diolah, 2018

Berdasarkan Tabel 2 dapat ditulis persamaan regresi linier berganda sebagai berikut.

$$
Y=-5,352+0,935 X_{1}+0,538 X_{2}+0,327 X_{3}
$$

Dimana :

$\mathrm{Y}=$ Komitmen organisasional karyawan

$\mathrm{X}_{1}=$ Kompensasi

$\mathrm{X}_{2}=$ Lingkungan kerja

$\mathrm{X}_{3}=$ Budaya organisasi

$\mathrm{R}^{\mathbf{2}}=$ Koefisien determinasi

Berdasarkan persamaan hasil regresi linear berganda melalui uji SPSS, dapat dijelaskan bahwa nilai koefisien $b_{1}=0,935$ bernilai positif yang menunjukkan bahwa kompensasi $\left(\mathrm{X}_{1}\right)$ berpengaruh positif terhadap komitmen organisasional karyawan (Y). Hal ini berarti semakin baik kompensasi maka semakin tinggi komitmen organisasional karyawan.

Nilai koefisien $b_{2}=0,538$ bernilai positif yang menunjukkan bahwa lingkungan kerja $\left(\mathrm{X}_{2}\right)$ berpengaruh positif terhadap komitmen organisasional 
karyawan (Y). Hal ini berarti semakin baik lingkungan kerja maka semakin tinggi komitmen organisasional karyawan.

Nilai koefisien $b_{3}=0,327$ bernilai positif yang menunjukkan bahwa budaya organisasi $\left(\mathrm{X}_{3}\right)$ berpengaruh positif terhadap komitmen organisasional karyawan (Y). Hal ini berarti semakin kuat budaya organisasi maka semakin tinggi komitmen organisasional karyawan.

Nilai koefisien regresi masing-masing variabel bebas bernilai positif dengan nilai signifikansi uji t kurang dari 0,05. Hal ini menunjukkan bahwa semua variabel bebas memiliki pengaruh positif yang signifikan terhadap variabel terikat.

Berdasarkan hasil analisis pengaruh kompensasi terhadap komitmen organisasional karyawandiperoleh nilai signifikasi sebesar 0,002 dengan nilai koefisien beta 0,935 . Nilai Signifikansi $0,002<0,05$ mengindikasikan bahwa $\mathrm{H}_{0}$ ditolak dan $\mathrm{H}_{1}$ diterima. Hasil ini mempunyai arti bahwa kompensasi berpengaruh positif dan signifikan terhadap komitmen organisasional karyawan PT. Harum Indah Sari Tours \& Travel Denpasar.

Kompensasi adalah balas jasa akan hasil kerja karyawan dalam bentuk finansial langsung maupun tidak langsung.Kompensasi tidak hanya berfungsi sebagai balas jasa semata, kompensasi dapat meningkatkan keinginan karyawan agar tetap berada dalam perusahaan. Kompensasi di ukur menggunakan tiga indikator yaitu gaji, bonus dan tunjangan.

Hasil analisis data menunjukkan kompensasimemberikan pengaruh positif terhadap komitmenorganisasional karyawan PT. Harum Indah Sari Tours \& TravelDenpasar. Pengaruh kompensasi di ukur menggunakan tiga indikator, yaitu 
gaji, tunjangan dan bonus. hal ini sesuai dengan hipotesis satu $\left(\mathrm{H}_{1}\right)$ bahwa kompensasi berpengaruh positif terhadap komitmen organisasional karyawan. Hasil penelitian ini sesuai dengan penelitian sebelumnya yang dilakukan oleh Rustini (2015), Buraidah (2013), Alamelu et al.(2015), dan Kee et al. (2016)yang mendapatkan hasil dalam bahwa kompensasi mempunyai pengaruh yang positif terhadap komitmen organisasional.

Semakin baik kompensasi yang diberikan PT. Harum Indah Sari Tours \& Travel Denpasar kepada karyawannya, maka semakin tinggi pula komitmen organisasional yang dimiliki karyawan karena karyawan merasa hasil kerjanya dinilai sebagaimana mestinya. Begitu pula sebaliknya, semakin buruk kompensasi yang diberikan perusahaan, maka semakin rendah komitmen organisasional karyawan. Kompensasi yang adil akan menumbuhkan rasa memiliki terhadap organisasi yang berdampak padameningkatnya komitmen karyawan pada organisasinya (Sudarwanti, 2007).

Berdasarkan hasil analisis pengaruh lingkungan kerja terhadap komitmen organisasional karyawandiperoleh nilai signifikansi sebesar 0,006 dengan nilai koefisien beta 0,538 . Nilai signifikansi $0,006<0,05$ mengindikasikan bahwa $\mathrm{H}_{0}$ ditolak dan $\mathrm{H}_{2}$ diterima. Hasil ini mempunyai arti bahwa lingkungan kerjaberpengaruh positif dan signifikan terhadap komitmen organisasional karyawan PT. Harum Indah Sari Tours \& Travel Denpasar.

Lingkungan kerja adalah segala sesuatu yang berada disekitar karyawan yang berbentuk fisik maupun non-fisik yang dapat mempengaruhi dirinya dalam menjalankan tugas-tugas yang dibebankan kepadanya. Lingkungan kerja yang 
baik dapat meningkatkan komitmen karyawan, jika lingkungan kerja buruk maka komitmen akan menurun. Lingkungan kerja di ukur melalui penerangan, kebersihan, ketersediaan fasilitas, keamanan lingkungan serta hubungan karyawan dengan pimpinan dan sesama karyawan.

Hasil analisis data menunjukkan bahwa lingkungan kerjamemberikan pengaruh positif terhadap komitmen organisasionalkaryawan PT. Harum Indah Sari Tours \& Travel Denpasar, hal ini sesuai dengan hipotesis dua $\left(\mathrm{H}_{2}\right)$ bahwa lingkungan kerja berpengaruh positif terhadap komitmen organisasionalkaryawan. Hasil penelitian ini sesuai dengan penelitian sebelumnya yang dilakukan oleh Penelitian yang dilakukan oleh Shalahuddin (2013), Saputra (2017), Hanaysha (2016), dan Okeoghene (2016) mendapatkan hasil bahwa lingkungan kerja berpengaruh positif terhadap komitmen organisasional.

Semakin baik lingkungan yang diberikan PT. Harum Indah Sari Tours \& Travel Denpasar kepada karyawannya maka semakin tinggi pula komitmen organisasional yang dimiliki karyawan karena karyawan merasa nyaman dalam lingkungan kerja disekitarnya. Begitu pula sebaliknya, semakin buruk lingkungan kerja yang diberikan perusahaan maka semakin rendah komitmenorganisasional karyawan. Apabila karyawan berada didalamlingkungan kerja yang nyaman akan mampu meningkatkan kepuasan dalam bekerja sehingga karyawan tersebut lebih berkomitmen terhadap organisasinya (Akhtar, 2014).

Berdasarkan hasil analisis pengaruh budaya organisasi terhadap komitmen organisasional karyawandiperoleh nilai signifikansi sebesar 0,000 dengan nilai koefisien beta 0,327 . Nilai signifikansi $0,000<0,05$ mengindikasikan bahwa 
$\mathrm{H}_{0}$ ditolak dan $\mathrm{H}_{3}$ diterima. Hasil ini mempunyai arti bahwa budayaorganisasi berpengaruh positif dan signifikan terhadap komitmen organisasional karyawan PT. Harum Indah Sari Tours \& Travel Denpasar.

Budaya organisasi adalah seperangkat asumsi dasar dan keyakinan yang dianut oleh anggota-anggota organisasi, kemudian dikembangkan dan diwariskan guna mengatasi masalah-masalah adaptasi eksternal dan masalah integrasi internal. Suatu organisasi untuk mencapai keberhasilan perlu meningkatkan faktor kinerja organisasi dengan membentuk dan mengembangkan suatu budaya organisasi yang mendukung terciptanya komitmen karyawan. Budaya organisasi di ukur melalui empat indikator, yaitu supportiveness, atmosphere, connectedness, dan formalization dengan masing-masing indikator memiliki beberapa butir pernyataan.

Hasil analisis data menunjukkan budaya organisasimemberikan pengaruh positif terhadap komitmenorganisasionalkaryawan PT. Harum Indah Sari Tours \& Travel Denpasar, hal ini sesuai dengan hipotesis tiga $\left(\mathrm{H}_{3}\right)$ bahwa budaya berpengaruh positif terhadap komitmen organisasional karyawan.Hasil penelitian ini sesuai dengan penelitian sebelumnya yang dilakukan oleh Fauzi dkk. (2016), Latib dkk. (2016), Sinha et al.(2017), dan Hamidi et al. (2017) yang mendapatkan hasil bahwa budaya organisasi memiliki pengaruh yang positif terhadap komitmen organisasional.

Semakin kuatbudaya organisasi yang digunakan di PT. Harum Indah Sari Tours \& Travel Denpasar maka akan semakin tinggi komitmen organisasionalyang dimiliki karyawan karena karyawan merasakan adanya 
kesesuaian nilai pribadi dengan nilai perusahaan. Begitu pula sebaliknya, semakin lemah budaya organisasiPT. Harum Indah Sari Tours \& Travel Denpasarmaka akan mengakibatkan semakin rendahnyakomitmen organisasional karyawan.Hasil tersebut sesuai dengan teori yang menyatakan bahwa budaya organisasi berfungsi sebagai perekat dan komitmen kolektif diantara seluruh anggota organisasi yang memberikan identitas organisasional bagi anggota dan membentuk stabilitas sistem sosial di dalam organisasi (Schein, 2004:12).

Besarnya pengaruh variabel bebas terhadap variabel terikat yang ditunjukkan oleh nilai determinasi total ( $R$ Square) sebesar 0,753 mempunyai arti bahwa sebesar 75,3 persen variasi komitmen organisasional karyawan PT. Harum Indah Sari Tours \& Travel Denpasardipengaruhi oleh variasi kompensasi, lingkungan kerja, dan budaya organisasi, sedangkan sisanya sebesar 24,7 persen djelaskan oleh faktor lain yang tidak dimasukkan ke dalam model.

Penelitian ini dapat memberikan informasi penting bagi PT. Harum Indah Sari Tours \& Travel Denpasar untuk dapat meningkatkan komitmen organisasional karyawannya. Berdasarkan hasil penelitian, kompensasi berpengaruh positif terhadap komitmen organisasional karyawan, hal ini berarti perusahaan diharapkan agar mempertahankan atau meningkatkan kompensasi berupa gaji, bonus, dan tunjangan sesuai dengan prestasi karyawan sehingga dapat meningkatkan komitmen organisasional karyawan. Hasil penelitian selanjutnya yaitu lingkungan kerja berpengaruh positif terhadap komitmen organisasional karyawan, hal ini berarti lingkungan kerja yang berupa penerangan, kebersihan, keamaan, fasilitas, dan hubungan dengan pimpinan maupun sesama karyawan 
harus dipertahankan sehingga karyawan merasa nyaman dan dapat meningkatkan komitmen organisasional karyawan. Hasil penelitian terakhir yaitu budaya organisasi berpengaruh positif terhadap komitmen organisasional karyawan, hal ini berarti perusahaan diharapkan agar mempertahankan budaya berupa normanorma dan nilai-nilai yang diterapkan di perusahaan tetap terjaga sehingga dapat meningkatkan komitmen organisasional karyawan untuk tetap tinggal di perusahaan.

\section{SIMPULAN DAN SARAN}

Berdasarkan hasil analisis yang telah diuraikan mengenai pengaruhkompensasi, lingkungan kerja, dan budaya organisasi terhadap komitmen organisasional karyawan PT. Harum Indah Sari Tours \& Travel Denpasar, maka diperoleh simpulan bahwa kompensasi berpengaruh positif terhadap komitmen organisasional karyawan yang artinya semakin baik kompensasi yang diberikan oleh perusahaan, maka semakin tinggi komitmen karyawan untuk tetap berorganisasi di perusahaan.Lingkungan kerja berpengaruh positif terhadap komitmen organisasional karyawan yang artinya semakin baik lingkungan kerja pada perusahaan, maka semakin tinggi komitmen karyawan untuk tetap berorganisasi di perusahaan.Budaya organisasi berpengaruh positif terhadap komitmen organisasional karyawan yang artinya semakin kuat budaya yang ada dalam suatu perusahaan, maka semakin tinggi komitmen karyawan untuk tetap berorganisasi di perusahaan.

Saran-saran yang dapat diberikan berdasarkan hasil penelitian adalah agar dapat meningkatkan dan menjaga komitmen organisasional karyawan, maka 
manajemen perusahaan sebaiknya memperhatikan waktu lama bekerja kayawan dalam pemberian kompensasi berupa gaji sehingga karyawan merasa komitmen untuk tetap berorganisasi di perusahaan dihargai, hubungan baik antara pimpinan dan karyawan harus lebih dijaga dan ditingkatkan maka akan terjadi komunikasi yang baik, sehingga kayawan merasa pekerjaan dan usaha yang dilakukannya didukung dan dihargai oleh pimpinan, serta budaya organisasi perusahaan dapat ditingkatkan dengan cara meningkatkan pelatihan keterampilan kepada karyawan dan menegaskan standar pekerjaan karyawan.

\section{REFERENSI}

Abidin, M. I Z. (2016). Pengaruh kepuasan kerja, lingkungan kerja dan efikasi diri terhdap komitmen organisasi di Rumah Sakit SMC Samarinda. Jurnal Ekonomi dan Keuangan. 13(1): 1-10.

Akhtar, J. (2014).Impact of work environment, salary package and employees perception on organizational commitment: a study of Small \& Medium Enterprises (SMEs) of Pakistan.International Journal of Academic Research in Business and Social Sciences. 4(8): 254-273.

Alamelu, R., Surulivel, S.T., Motha, L.C.S., Amudha, S., \& Selvabaskar, S. (2015). Correlates of employee compensation and commitment. Mediterranean Journal of Social Sciences. 6(5): 335-341.

Anvari, R., Salmiah, M.A., Ahmad, U.N.U., Seliman,S., \& Garmsari, M. (2011). The relationshipbetween strategic compensation practices andaffective organizational commitment.Journal Of Research In Business. 1(2): 4455.

Basuki \& Susilowati, I. (2005). Dampak kepemimpinan, dan lingkungan kerja, terhadap temangat kerja. JRBI. 1(1): 31-47.

Fauzi, M., Warso, M,M.\& Haryono, A,T. (2016). Pengaruh budaya organisasi dan kepuasan kerja terhadap kinerja karyawan dengan komitmen organisasi sebagai variabel intervening (studi pada karyawan PT. Toys Games Indonesia Semarang). Journal of Management.. 2(2): 1-15.

Greenberg, J.\&Baron, R. A. (2008). Organizational Behavior. International New Jersey: Pearson Education, Inc. 
Haar, J. M. 2006. Challenge and hindrance stressors in New Zealand: exploring social exchange theory outcomes. International Journal of Human Resource Management. 17(11): 1942-1950.

Habib, S., Saira, A., Amjad, H., Sana, Y., \& Muhammad, I. (2014). The impact of organizational culture on job satisfaction, employess commitment and turn over intention. Advances in Economics and Business. 2(6): 215222.

Hamidi, Y., Mohammadibakhsh, R., Soltanian, A., \&Behzadifa, M. (2017). Relationship between organizational culture and commitment of employees in health care centers in westof Iran. Electronic Physician. 9(1): 3646-3652.

Hanaysha, J. (2016). Testing the effects of employee engagement, work environment, and organizational learning on organizational commitment. Procedia - Social and Behavioral Sciences. 229: 289-297.

Hasibuan, M. S.P. (2012). Manajemen Sumber Daya Manusia. Edisi Revisi. Jakarta: Bumi Aksara.

Inanlou, Z. (2017). The effect of organizational culture on employee commitment: a mediating role of human resource development in Korean Firms. The Journal of Applied Business Research. 33(1): 87-94.

Ivancevich, J. M., Robert, K., \& Michel T. M. (2007). Perilaku dan Manajemen Organisasi, Jilid 1. Jakarta : PT. Gelora Aksara Pratama.

Kee, L. B., Ahmad, R. B., \& Abdullah, S. M. (2016). Relationship between finansial compensation and organizational commitment among Malaysian Bank Workers.Asian Business Research. 1(1): 75-85.

Korir, I. \& Kipkebut, D. (2016). The effect of reward management on employees commitment in the Universities in Nakuru County-Kenya. Journal of Human Resource Management. 4(4): 37-48.

Kreitner, R. \& Kinicki, A. (2005). Perilaku Organisasi. Jakarta : Salemba Empat.

Kuntjoro, Z.S. (2002). Komitmen Organisasi. Artikel. www.e-psikologi.com. Diakses 20 April (2017).

Latib, L., Fathoni,A., \& Minarsih, M,M. (2016). Pengaruh budaya organisasi, kepemimpinan dan motivasi terhadap komitmen organisasi dan kinerja pegawai (studi pegawai Dinas Pasar Kota Semarang). Journal Of Management. 2(2). 1-13.

Mariam, R. (2009). Pengaruh gaya kepemimpinan dan budaya organisasi terhadap kinerja karyawan melalui kepuasan kerja karyawan sebagai variabel intervening. Tesis Universitas Diponogoro, Semarang. 
Martoyo, S. (2007). Manajemen Sumber Daya Manusia. Edisi 5.Cetakan Pertama. Yogyakarta: BPFE.

Michael, L.\& Harold, W. P., 1993. Money is Everything. Annual Report HR.

Moekijat. 2003. Manajemen Kepegawaian. Jakarta : PT Bumi Aksara.

Muljani, N. (2002). Kompensasi sebagai motivator untuk meningkatkan kinerja karyawan. Jurnal Manajemen \& Kewirausahaan. 4(2): 108-122.

Nawab, S. \& Komal K. B. (2011). Influence of employee compensation on organizational commitment and job satisfaction: a case study of educational sector of Pakistan. International Journal of Business and Social Science. 2(8): 25-32.

Okeoghene, M. A. \& Aina, F.R. (2016). Work environment and organizational commitment of staff in Academic Libraries in Lagos State, Nigeria. Journal of Applied Information Science and Technology. 9(1): 39-48.

Puspitawati, Ni Made Dwi. (2014). Pengaruh kepuasan kerja terhadap komitmen organisasional dan kualitas layanan. Jurnal Manajemen Strategi Bisnis dan Kewirausahaan Universitas Udayana Bali. 8(1): 68-80.

Robbins, S.P. (2008). Organizational Behavior (11th ed). New Jersey: Prentice Hall.

Rustini, Ni Komang Ayu. (2015). Pengaruh kompensasi dan lingkungan kerjapada komitmen organisasi dan implikasinyapada kinerja pengelola anggaran (studi empiris pada Satuan Kerja Perangkat DaerahPemerintah Kabupaten Tabanan). Jurnal Buletin Studi Ekonomi. 20(2): 123-129.

Saputra, A. \& Andri, S. (2017). Pengaruh lingkungan kerja dan komitmen organisasi terhadap kepuasan kerja karyawan (studi kasus pada Hotel Ratu Mayang Garden Pekanbaru). JOM FISIP. 4(2): 1-15.

Schein, E. H. (2004). Organizational Culture and Leadership. Third edition. San Fransisco: Jossey-Bass. Inc

Sedarmayanti. (2009). Sumber Daya Manusia dan Produktivitas Kerja. Bandung: CV Mandar Maju.

Shalahuddin, A. (2013). Pengaruh kepemimpinan dan lingkungan kerja terhadap komitmen organisasional dan kinerja karyawan PT. Sumber Djantin di Kalimantan Barat. Jurnal Manajemen Teori dan Terapan. 6(1): 90-104.

Sinha, A.K., Kumar, R., Sengupta, P.P., \& Bandyopadhyay, G. (2017). Impact of organization's culture on employees' commitment: evidence from five homogeneous units under a group of company operating in different states in India. Journal of Business Studies Quarterly. 8(3): 89-105. 
Simamora, H. (2014). Manajemen Sumber Daya Manusia. Yogyakarta. YPPKN.

Smirnova, A., Manuati Dewi, I.G.A., \& Surya Putra, M. (2017). Pengaruh dimensi budaya organisasi terhadap turnover intention ekspatriat pada hotel bintang lima di Nusa Dua-Bali. E-Jurnal Ekonomi dan Bisnis Universitas Udayana. 6(2): 417-444.

Sopiah. (2008). Perilaku Organisasi. Yogyakarta: Andi.

Sudarwanti. (2007). Analisis pengaruh keadilan kompensasi, peran kepemimpinan dan kepuasan kerja terhadap komitmen organisasi dalam meningkatkan kinerjapegawai. Tesis Universitas Diponogoro, Semarang.

Susanto, A.B. \& Prama, G. (2006). Strategi Organisasi. Yogyakarta: Amara Books

Ushie, E. M., Agba, A. M. O., \& Okorie, C. (2015).Work environment and employees' commitment in agro-based industries in Cross River State, Nigeria. Global Journal of Human-Social Science: (C) Sociology \&Culture.15(6): 9-15.

Wukir. (2013). Manajemen Sumber Daya Manusia dalam Organisasi Sekolah. Yogyakarta: Multi Presindo.

Yamali, F. R. (2018). Effect of compensation, competencies and organizational cultureon organizational commitment its implicationson experts performance of construction services company in Jambi Province. International Journal of Advances in Management and Economics. 7(2): 29-42.

Yaseen, A. (2013). Effect of compensation factors on employee satisfaction a study of doctor dissatifaction in Punjab. International Journal of Human Resource Studies. 3(1): 142-157. 